\title{
The Effects of Gamified Flipped Learning Method on Student's Innovation Skills, Self-Efficacy towards Virtual Physics Lab Course and Perceptions
}

\author{
Hana Dler Ahmed *(D) and Gulsum Asiksoy (D) \\ Department of Education and Instructional Technology, Near East University, 99138 Nicosia (Via Mersin 10 \\ Turkey), North Cyprus, Cyprus; gulsum.asiksoy@neu.edu.tr \\ * Correspondence: hana.majeed90@yahoo.com
}

Citation: Ahmed, H.D.; Asiksoy, G. The Effects of Gamified Flipped Learning Method on Student's Innovation Skills, Self-Efficacy towards Virtual Physics Lab Course and Perceptions. Sustainability 2021, 13, 10163. https://doi.org/ 10.3390/su131810163

Academic Editor: Changhyun Roh

Received: 28 July 2021

Accepted: 3 September 2021

Published: 10 September 2021

Publisher's Note: MDPI stays neutral with regard to jurisdictional claims in published maps and institutional affiliations.

Copyright: (C) 2021 by the authors Licensee MDPI, Basel, Switzerland. This article is an open access article distributed under the terms and conditions of the Creative Commons Attribution (CC BY) license (https:// creativecommons.org/licenses/by/ $4.0 /)$.

\begin{abstract}
Laboratory courses are extremely important in Physics education in terms of providing a better understanding of the theoretical course subjects by the students. However, since the COVID-19 epidemic caused education to be carried out remotely and digitally all over the world, practical as well as theoretical courses were moved to digital platforms. Therefore, this study investigated the effects of the Gamified Flipped Learning (GFL) method on students' physics self-efficacy and innovation skills in a virtual physics laboratory course. The study was carried out with true experimental design and the participants were a total of 70 first-year engineering students, which were randomly divided into two groups. The experimental group was trained with the GFL method, the control group was trained with Classical Flipped Learning (CFL) method. Data were collected from a physics self-efficacy questionnaire, innovative skills questionnaire, and semi-structured interviews form. The research results showed that GFL method has a positive impact on the innovation skills of students although insignificant improvement was introduced by gamified-flipped learning on students' selfefficacy. In addition, the interviews with the students revealed a positive perception of gamification, by mentioning some important aspects of the process that were extremely beneficial.
\end{abstract}

Keywords: flipped learning; gamification; innovation skills; self-efficacy; virtual lab

\section{Introduction}

Lately, researchers and academics over the world have been faced with a common challenge of providing effective mentoring and tutoring to students in the absence of the traditional teaching environment. During the early stages of the development of flipped learning - a teaching approach suitable for this prevailing condition-it was faced with severe opposition, as professionals were clearly left unconvinced by the possibility of it having a successful implementation. Yet, flipped learning has become the approach of choice for some, and probably the only feasible one for others [1]. The scholars argued that even though it proffers a novel approach to instruction, it grossly increases the workload of instructors as they are faced with an enormous responsibility of preparing detailed material for the class-an added task [2]. On the other hand, it was gathered that students also tend to face a challenge of self-management and discipline during flipped learning classes as many tend to enjoy boundless internet usage outside the scope of the classroom needs. Irrespective of these inherent challenges associated with the flipped learning and its implementation as identified by scholars, the flipped learning approach has seen widely acceptance due to its unique suitability for switching students from being passive receivers to being involved in the process as active learners [1]. In more specialized fields, flipped learning has found applicability; [3] discussed its applicability in the area of medical education, and [4] described its significance to the field of Pharmacy. The flipped classroom method requires that the classroom activities take place after instructional materials such as videos have been provided to the students. Classroom activities thus 
are reduced to improve students' engagement by requiring that they make inquiries and/or seek to clarify confusing sections of studied materials [5]. It seeks to provide a more student-focused classroom environment, in contrast to the traditional teacherfocused classroom environment, thereby creating an inversion of the traditional teaching approach [6]. Also, Jang and Kim [7] recognized that flipped learning has a higher affective and interpersonal impact than cognitive on students.

Gamification, an important practice in Human-Computer Interaction is the application of the components of game design and traits that seek to improve the learning of students, due to their natural inclination to enjoy games [8-10]. Landers and Armstrong [11] identified in their study that prior experiences like familiarity with video games have an influence on the effect of gamification. Some studies indicate that gamification contributes positively to students' motivation, performance, and goal determination [12-14]. Several elements such as avatars, levels, points, and gifts make up the gamified environment $[15,16]$. These elements are crucial due to the role they play in the stimulation of the interests of the students for better academic performance [17].

Several authors have studied the effects of a gamification and flipped learning mix in teaching. In a theoretical study by [18], it was identified that gamifying flipped learning English as a Foreign Language (EFL) course improves students' engagement and promotes their language learning optimism. Also on engagement, considering a focus group of undergraduate students, Huang et al. [19] identified that students' engagement was improved by a gamified flipped learning class as students subjected to it had significantly higher scores in their tests compared with others who were not. Gunduz and Akkoyunlu in [20] investigated the impacts of gamified flipped learning on participation and achievement, they gathered that the gamified flipped learning method promoted these variables. Zou [21] tried to identify the perception of teachers and students alike in a gamified flipped learning primary school classroom for EFL, while Zainuddin et al. [22] sought to identify the effects of gamified flipped learning on the performance and outcome of learners. Zainuddin et al. [22] identified that learners in the gamified flipped setting were highly motivated than others due to the fact that their psychological needs were met.

Although several gamified flipped learning studies exist in the literature, they are scarce when compared to the vast number of independent papers on gamification or flipped learning available [23-28]. Scarcer are the ones that address the innovation skills and physics self-efficacy of students. In this paper, using an online physics lab class, we seek to cover this gap by investigating the impact that Gamified Flipped Learning (GFL) method has on the physics self-efficacy, perception, and innovation skills of students. In order to do this, the research aims to clearly answer the following questions:

1. Can the gamified flipped learning improve students' innovation skills?

2. Can the gamified flipped learning increase students' physics self-efficacy?

3. What are the students' opinions on gamification?

\section{Literature Review}

\subsection{Gamification}

Gamification, loosely defined as the approach of representing a process like a game [29], is not novel in the general sense of application. Historically, humans have always desired and sought to make daily activities appear more appealing and motivating by making games out of them. An octet of Meaning, Accomplishment, Empowerment, Social Influence, Unpredictability, Avoidance, Scarcity, and Ownership holds the major drives for a successful gamification campaign [29]. Some studies show the versatility of gamification by its applicability in several fields and disciplines such as in the marketing context [30], in production and logistics [31], and in motivational information system [32].

As we seek to measure the impact of gamified flipped learning on the innovation skill and physics self-efficacy of students, other authors have delved into similar studies. In a general view, Zainuddin et al. [9] investigated the effects gamification has on learning and instruction, they discovered that gamification has the capacity to stimulate the motivation, 
engagement and social influence of the learner. Students' academic achievement within the gamified learning framework was also noted to have improved, as motivated learners were actively engaged in the learning activities. Aldemir et al. [33] identified that gamification was responsible for increasing the motivation of learners through the introduction of competition, challenge, socialization, and imagination. On the other hand, Jurgelaitis et al. [34] acknowledged the effect of gamification on improved intrinsic motivation of the learners. Several elements of the gamification environments play key roles in its overall effect on learners as identified in [35,36]. They gathered that competitions have a positive significance on the engagement of the students based on their behavior, emotion and cognition. Although badges are significant elements of the gamification setup, Kyewski and Krämer [37] showed that they did not necessarily improve the intrinsic motivation of the learners who encounter them. In [38], using gamified workshops, some researchers investigated the benefits of gamification to the ability of 537 students to retain the knowledge they just acquired. The activities covered the entire day in the form of field trips laced with an enrichment of several games. It was discovered that over an extended period of time, the students that participated in the gamified activities had better retention.

The role of emotions in gamification was researched by [39], in which it was recognized that gamification and its experiences propel both positive and negative emotions, proposing that emotion should receive thorough consideration in the design of gamified systems. From the recent study on the effect of gamification on student's learning in [8], by conducting a quasi-experimental study with 473 university students, it was revealed that students who were able to complete a higher number of quizzes in the gamified environment were also able to perform better in a subsequent test than others. Also, comparing students' current academic performance, their study revealed that gamification was more effective for students who already have a high academic performance that those who did not. They went further to identify instances exist where gamification would be counter-productive to students with poor academic performance.

Considering the impact of a GFL method on students, from the literature it is seen that a well-designed gamified environment promotes performance improvement by increasing the engagement and motivation of learners, thus increasing their participation.

\subsection{Gamification and Flipped Learning}

From the literature, papers investigating gamification in the context of flipped learning are still limited. In the study of [40], gamification was perceived as a complement to flipped learning. The authors conducted a quasi-experimental study with a quantitative methodology in which two study groups namely the control and the experimental groups, consisting of 60 year-four secondary school students were considered. It was concluded from the study that gamifying the face-to-face segment of the flipped learning presents enormous abilities to improve motivation, student-teacher and student-student communications as verified by other related studies [6,41]. Three different instructional methods were applied in the study conducted by [42] while investigating the cognitive engagement and achievement of secondary school mathematics students. Employing a mixed method of research consisting of tests and interviews, it was identified that students who were exposed to the flipped learning method had significantly better performances that those who were not, and gamified flipped method improved the cognitive engagement of the students than independent gamified study and traditional classroom. Also, from the interview data that was gathered, it was recognized that the communication and interactive activities conducted during the gamified flipped learning session greatly promoted the cognitive engagement and achievement of students who were present within the gamified flipped learning.

In another study, Zou [21] investigated the perception of both primary school pupils and their teachers towards gamified flipped learning during their English as a Foreign Language class sessions. They further tried to determine if there was a correlation between the perception of these pupils and those of their teachers and why, if there are. After a 
year of the study, it was concluded that both students and their teachers believed that the gamified flipped learning promoted the motivation to learn and engagement among other things.

Even though several papers exist on the subjects of flipped learning, gamification, motivation, and perception individually or in different mixes [1-6], we intend to bridge the gap of an absence of data on the impact of combining flipped learning with gamification on motivation, physics self-efficacy, and perception of university students.

\section{Method}

\subsection{Design of the Research}

The true-experimental design was applied in this research, consisting of a control group and an experimental group to learn topics. Students were randomly assigned to the experimental group or the control group. In the control group, students were taught using the classical flipped learning (CFL) method while the gamified flipped learning (GFL) method was applied in the experimental group. This is shown in Figure 1.

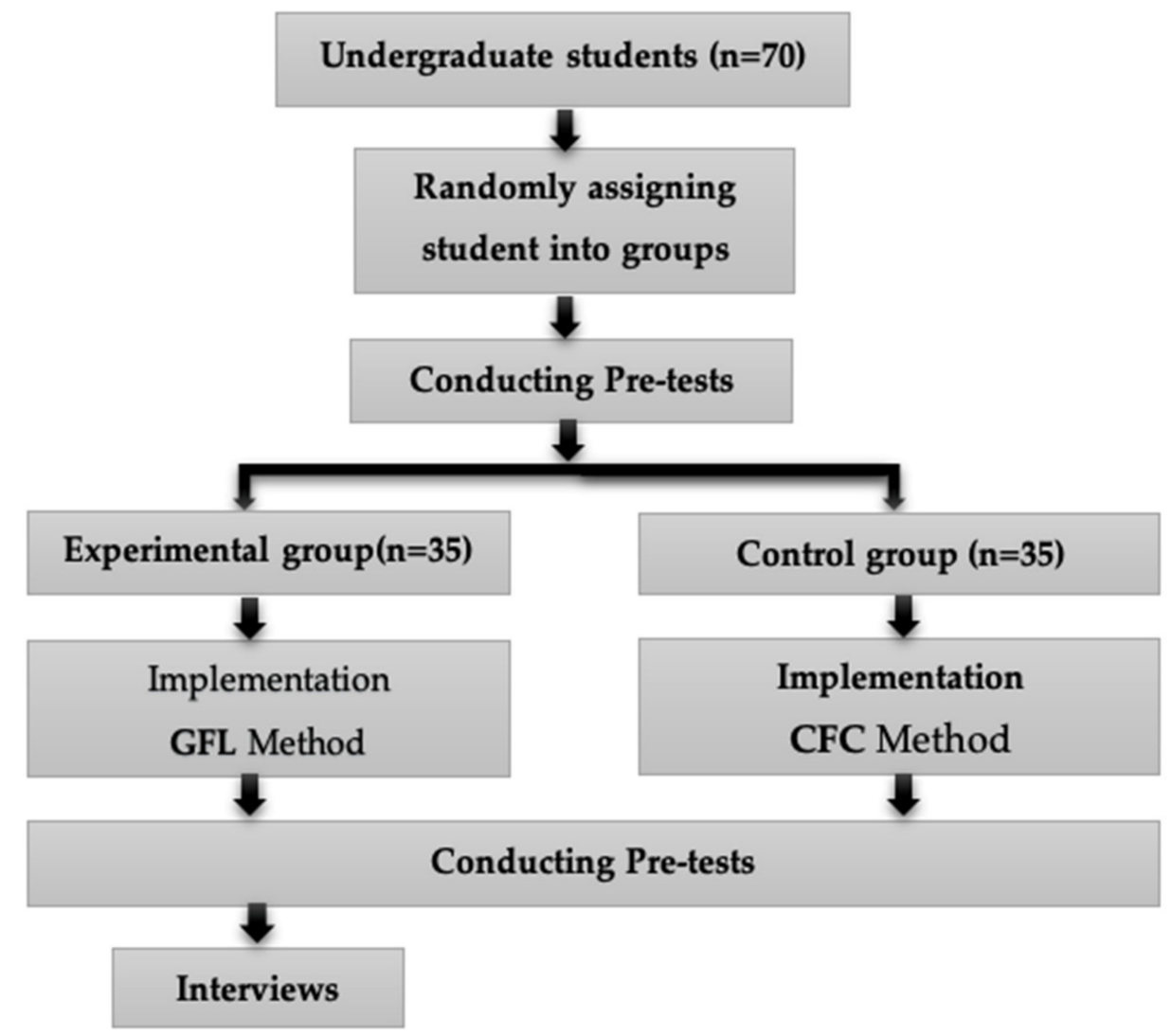

Figure 1. The Design of the Research.

\subsection{Data Collection Tools}

As described earlier, data collection was done for both stages of the study. During the pre-class stage, data was collected using questionnaires to ascertain that both groups had equal gamification experiences and perceptions. Data gathered from the questionnaire was aimed at identifying the impacts of the gamified flipped learning procedure on the physics self-efficacy and innovative skills of the students. Specifically, innovation was measured using a 5-point Likert scale that ranged from Strongly disagree, through Neither Disagree nor Agree to Strongly Agree, while physics self-efficacy was measured on a 5points Likert scale also, ranging from Strongly Agree through Neither Agree nor Disagree to Strongly Disagree. After the online lab/gamification phase of the study, an interview was conducted with the experimental group of students in order to identify how they 
perceived the gamification process. In addition, Log files were used for students' quiz submission data. Several indicators were used in the measurement of the research variable.

\subsection{Participants}

The study comprised of 70 participants from the first-year undergraduate Physics lab class, of which 58 were males and 12 were female. The students were from various departments in a private university during the 2020-2021 academic year. The experimental group with 35 participants used the GFL method, while the control group having 35 participants employed only the CFL method. A single instructor taught both groups, comprising of young students with ages between 17 and 29, for a period of 10 weeks.

Pre-test Evaluation: As a pre-test, a questionnaire of innovation skill and physics selfefficacy was administered to the students in order to determine if both groups considered in the study (Experimental and Control) had similar perceptions of gamification and its practices. As a result of this, data was gathered and analyzed. Independent sample t-test results according to the innovation skill pre-test results are shown in Table 1.

Table 1. Pre-test score of innovation skill.

\begin{tabular}{|c|c|c|c|c|c|c|c|}
\hline \multicolumn{2}{|l|}{ Group } & \multirow{3}{*}{$\begin{array}{l}\mathbf{N} \\
35 \\
35\end{array}$} & \multirow{3}{*}{$\begin{array}{l}\text { Mean } \\
2.4286 \\
2.6000\end{array}$} & \multirow{3}{*}{$\begin{array}{c}\begin{array}{c}\text { Std. } \\
\text { Deviation }\end{array} \\
0.91670 \\
0.94558\end{array}$} & \multirow{3}{*}{$\begin{array}{c}\begin{array}{c}\text { Std. } \\
\text { Error Mean }\end{array} \\
0.15495 \\
0.15983\end{array}$} & \multirow{3}{*}{$\begin{array}{c}t \\
0.77008\end{array}$} & \multirow{3}{*}{$\begin{array}{c}p \\
0.44392\end{array}$} \\
\hline I like to think about a new & Experiment & & & & & & \\
\hline project approach & Control & & & & & & \\
\hline \multirow{2}{*}{$\begin{array}{l}\text { I like to find new challenging to develop } \\
\text { new products in my own discipline }\end{array}$} & Experiment & 35 & 2.2000 & 0.93305 & 0.15771 & 1.88106 & 0.06425 \\
\hline & Control & 35 & 2.6286 & 0.97274 & 0.16442 & & \\
\hline \multirow{2}{*}{$\begin{array}{l}\text { I like to think about how work can } \\
\text { be improved }\end{array}$} & Experiment & 35 & 2.5429 & 0.91853 & 0.15526 & 0.39213 & 0.69619 \\
\hline & Control & 35 & 2.6286 & 0.91026 & 0.15386 & & \\
\hline \multirow[t]{2}{*}{ I see complex problems as challenging } & Experiment & 35 & 2.5429 & 0.91853 & 0.15526 & 0.25570 & 0.79895 \\
\hline & Control & 35 & 2.4857 & 0.95090 & 0.16073 & & \\
\hline \multirow{2}{*}{$\begin{array}{l}\text { I like to find a new solution to an } \\
\text { existing problem }\end{array}$} & Experiment & 35 & 2.5714 & 0.81478 & 0.13772 & 0.81252 & 0.41933 \\
\hline & Control & 35 & 2.4000 & 0.94558 & 0.15983 & & \\
\hline \multirow{2}{*}{$\begin{array}{l}\text { I am good at combining } \\
\text { different disciplines }\end{array}$} & Experiment & 35 & 2.7429 & 0.65722 & 0.11109 & 0.13963 & 0.88937 \\
\hline & Control & 35 & 2.7143 & 1.01667 & 0.17185 & & \\
\hline \multirow{2}{*}{$\begin{array}{l}\text { I can link new ideas to existing ideas } \\
\text { (of others). }\end{array}$} & Experiment & 35 & 2.5429 & 0.98048 & 0.16573 & 0.66921 & 0.50563 \\
\hline & Control & 35 & 2.6857 & 0.79600 & 0.13455 & & \\
\hline \multirow{2}{*}{$\begin{array}{l}\text { I see my assignment/project as } \\
\text { challenging }\end{array}$} & Experiment & 35 & 2.4857 & 0.91944 & 0.15541 & 0.88858 & 0.37736 \\
\hline & Control & 35 & 2.6857 & 0.96319 & 0.16281 & & \\
\hline \multirow{2}{*}{$\begin{array}{l}\text { I find my assignment/project } \\
\text { field interesting }\end{array}$} & Experiment & 35 & 2.6000 & 1.14275 & 0.19316 & 0.23058 & 0.81833 \\
\hline & Control & 35 & 2.5429 & 0.91853 & 0.15526 & & \\
\hline \multirow[t]{2}{*}{ I am good at my work } & Experiment & 35 & 2.5143 & 1.03955 & 0.17572 & 1.78461 & 0.07878 \\
\hline & Control & 35 & 2.9429 & 0.96841 & 0.16369 & & \\
\hline \multirow{2}{*}{ I can do my core tasks in a routine manner } & Experiment & 35 & 2.4286 & 1.00837 & 0.17045 & 2.00147 & 0.04933 \\
\hline & Control & 35 & 2.9714 & 1.24819 & 0.21098 & & \\
\hline
\end{tabular}

Significant at 0.05 .

Considering the innovation skill of the students, it can be seen from the results of the statistical analysis that the pre-test generally did not significantly differ between the experimental group and the control group based on the respective $p$ values $(p>0.05)$, except for the last variable in Table 1. This finding indicates that the experimental and control groups were equal regarding innovation skills before the experimental implementation. Independent sample t-test results according to the physics self-efficacy pre-test results are shown in Table 2. 
Table 2. Pre-test scores of self-efficacy.

\begin{tabular}{|c|c|c|c|c|c|c|c|}
\hline \multicolumn{2}{|l|}{ Group } & \multirow{3}{*}{$\begin{array}{l}\mathbf{N} \\
35 \\
35\end{array}$} & \multirow{3}{*}{$\begin{array}{l}\text { Mean } \\
3.6286 \\
4.0000\end{array}$} & \multirow{2}{*}{$\begin{array}{c}\begin{array}{c}\text { Std. } \\
\text { Deviation }\end{array} \\
1.11370\end{array}$} & \multirow{2}{*}{$\begin{array}{c}\begin{array}{c}\text { Std. Error } \\
\text { Mean }\end{array} \\
0.18825\end{array}$} & \multirow{2}{*}{$\begin{array}{c}t \\
1.41348\end{array}$} & \multirow{2}{*}{$\begin{array}{c}p \\
0.16208\end{array}$} \\
\hline I can understand the important concepts in the physics & Experiment & & & & & & \\
\hline lab book & Control & & & 1.08465 & 0.18334 & & \\
\hline I can design examples about the content of the physics & Experiment & 35 & 3.7429 & 1.14642 & 0.19378 & 0.52465 & 0.60153 \\
\hline lab book & Control & 35 & 3.8857 & 1.13167 & 0.19129 & & \\
\hline \multirow{2}{*}{$\begin{array}{l}\text { I can use my physics knowledge to understand the problem } \\
\text { discussions in the physics lab book }\end{array}$} & Experiment & 35 & 3.7714 & 0.84316 & 0.14252 & 0.00000 & 1.00000 \\
\hline & Control & 35 & 3.7714 & 0.94202 & 0.15923 & & \\
\hline \multirow{2}{*}{$\begin{array}{l}\text { I can write a simple example about any physics subject I } \\
\text { have learned. }\end{array}$} & Experiment & 35 & 3.7429 & 1.09391 & 0.18490 & 0.78844 & 0.43318 \\
\hline & Control & 35 & 3.9429 & 1.02736 & 0.17366 & & \\
\hline \multirow[t]{2}{*}{ I can understand physics lab terms } & Experiment & 35 & 3.6571 & 1.05560 & 0.17843 & 0.67455 & 0.50225 \\
\hline & Control & 35 & 3.8286 & 1.07062 & 0.18097 & & \\
\hline \multirow{2}{*}{$\begin{array}{l}\text { I can make an effective use of my knowledge while solving } \\
\text { physics lab problems. }\end{array}$} & Experiment & 35 & 3.6571 & 1.02736 & 0.17366 & 0.81212 & 0.41956 \\
\hline & Control & 35 & 3.8571 & 1.03307 & 0.17462 & & \\
\hline \multirow{2}{*}{$\begin{array}{l}\text { I can make connections between recently learned subjects and } \\
\text { my physics lab knowledge. }\end{array}$} & Experiment & 35 & 3.9714 & 0.95442 & 0.16133 & 0.63651 & 0.52658 \\
\hline & Control & 35 & 3.8286 & 0.92309 & 0.15603 & & \\
\hline \multirow{2}{*}{ I can discover little things by using physics theorems. } & Experiment & 35 & 3.8286 & 1.07062 & 0.18097 & 0.35413 & 0.72434 \\
\hline & Control & 35 & 3.9143 & 0.95090 & 0.16073 & & \\
\hline \multirow{2}{*}{ I can make connections between physics lab terms. } & Experiment & 35 & 3.9429 & 1.10992 & 0.18761 & 0.67809 & 0.50002 \\
\hline & Control & 35 & 3.7714 & 1.00252 & 0.16946 & & \\
\hline \multirow{2}{*}{$\begin{array}{l}\text { I can interpret a physics lab subject I have seen for the first } \\
\text { time with my previous knowledge. }\end{array}$} & Experiment & 35 & 3.6286 & 1.05957 & 0.17910 & 0.49727 & 0.62061 \\
\hline & Control & 35 & 3.7429 & 0.85209 & 0.14403 & & \\
\hline \multirow{2}{*}{$\begin{array}{l}\text { I can identify the important physics lab points of a physics } \\
\text { lab subject I read about. }\end{array}$} & Experiment & 35 & 3.8286 & 1.01419 & 0.17143 & 0.22158 & 0.82531 \\
\hline & Control & 35 & 3.7714 & 1.13981 & 0.19266 & & \\
\hline I know how to behave when I encounter a new challenge in & Experiment & 35 & 3.5429 & 0.95001 & 0.16058 & 2.35135 & 0.02161 \\
\hline physics lab. & Control & 35 & 4.0857 & 0.98134 & 0.16588 & & \\
\hline & Experiment & 35 & 4.0286 & 0.98476 & 0.16645 & 0.48072 & 0.63226 \\
\hline I believe that I have the ability to learn physics lab. & Control & 35 & 4.1429 & 1.00419 & 0.16974 & & \\
\hline I know how I can make an effective use of my previous & Experiment & 35 & 3.6857 & 1.07844 & 0.18229 & 1.57984 & 0.11879 \\
\hline knowledge when I encounter a new challenge in physics lab. & Control & 35 & 4.0857 & 1.03955 & 0.17572 & & \\
\hline I can use my physics lab knowledge to learn similar concepts & Experiment & 35 & 3.6286 & 1.23873 & 0.20938 & 1.06958 & 0.28859 \\
\hline in other lessons. & Control & 35 & 3.9143 & 0.98134 & 0.16588 & & \\
\hline I can find clues in physics lab problems. & Experiment & 35 & 3.6857 & 1.13167 & 0.19129 & 0.59537 & 0.55357 \\
\hline & Control & 35 & 3.8286 & 0.85700 & 0.14486 & & \\
\hline I can solve physics lab problems by using & Experiment & 35 & 3.6000 & 1.09006 & 0.18425 & 0.11868 & 0.90588 \\
\hline self-specific solutions. & Control & 35 & 3.5714 & 0.91670 & 0.15495 & & \\
\hline I can concentrate in physics lab sessions. & Experiment & 35 & 3.7714 & 1.11370 & 0.18825 & 1.03720 & 0.30332 \\
\hline & Control & 35 & 4.0286 & 0.95442 & 0.16133 & & \\
\hline I strongly believe that I can solve a difficult physics & Experiment & 35 & 3.8857 & 1.15737 & 0.19563 & 0.21082 & 0.83366 \\
\hline lab problem. & Control & 35 & 3.9429 & 1.10992 & 0.18761 & & \\
\hline I can guarantee the accuracy of a result I find for a physics & Experiment & 35 & 3.8000 & 1.20782 & 0.20416 & 0.21270 & 0.83219 \\
\hline lab problem. & Control & 35 & 3.8571 & 1.03307 & 0.17462 & & \\
\hline & Experiment & 35 & 3.8857 & 1.02244 & 0.17282 & 0.00000 & 1.00000 \\
\hline I can get compliments for my physics lab homework. & Control & 35 & 3.8857 & 1.05081 & 0.17762 & & \\
\hline I always have a feeling that I solve a physics lab & Experiment & 35 & 3.8000 & 1.07922 & 0.18242 & 0.10769 & 0.91456 \\
\hline problem correctly. & Control & 35 & 3.7714 & 1.13981 & 0.19266 & & \\
\hline I can get good marks in physics lab exams. & Experiment & 35 & 3.9429 & 1.16171 & 0.19637 & 0.00000 & 1.00000 \\
\hline 1 can get good marks in pnysics rao exams. & Control & 35 & 3.9429 & 1.02736 & 0.17366 & & \\
\hline & Experiment & 35 & 3.5714 & 1.14496 & 0.19353 & 1.74635 & 0.08527 \\
\hline I can solve physics lab problems by concretizing them. & Control & 35 & 4.0286 & 1.04278 & 0.17626 & & \\
\hline I can make a good solution plan for physics lab problems. & Experiment & 35 & 3.4857 & 0.98134 & 0.16588 & 2.31473 & 0.02365 \\
\hline 1 can make a good solution plan for pnysics lab problems. & Control & 35 & 4.0000 & 0.87447 & 0.14781 & & \\
\hline & Experiment & 35 & 3.7714 & 1.03144 & 0.17434 & 0.33382 & 0.73954 \\
\hline I have my own ideas about questions related to physics lab. & Control & 35 & 3.8571 & 1.11521 & 0.18851 & & \\
\hline & Experiment & 35 & 3.7429 & 1.01003 & 0.17073 & 0.11878 & 0.90580 \\
\hline 1 can analyze the event in a physics problem. & Control & 35 & 3.7714 & 1.00252 & 0.16946 & & \\
\hline & Experiment & 35 & 3.8571 & 1.08852 & 0.18399 & 0.00000 & 1.00000 \\
\hline I study alone to solve problems in the learning step. & Control & 35 & 3.8571 & 1.03307 & 0.17462 & & \\
\hline I think with a physics lab mentality when planning daily & Experiment & 35 & 3.8824 & 1.12181 & 0.19239 & 0.54316 & 0.58882 \\
\hline life events. & Control & 35 & 3.7429 & 1.01003 & 0.17073 & & \\
\hline
\end{tabular}


Considering the physics self-efficacy skill of the students, with the exception of 2 variables ("I can use my physics lab knowledge to learn similar concepts in other lessons" and "I can make a good solution plan for physics lab problems"), it can be seen from the results of the statistical analysis that the pre-test generally did not significantly differ between the experimental group and the control group based on the respective $p$ values $(p>0.05)$. This finding indicates that before implementation, both groups had equal physics self-efficacy.

\subsection{Instructional Environment}

In the Moodle learning management structure, pages associated with each group were created for different courses, and students were required to access the courses by entering a unique username and password. For each group, the Moodle was thoroughly loaded with essential resources among which are chat messaging, feedback, quizzes among others, but additionally, the experimental group had gamification functions that were added through the use of a gamification plug-in. Liberty was given to the participants to decide whether to or not to complete the out-of-class activities.

Prior to the start of the experiment, all the students according to their groups were informed of the learning procedure to be expected. The students in the experimental group were informed that they would be instructed using the gamified flipped learning method while the students in the control group were told to expect something different, as they would be instructed using only the flipped method.

For both groups, the course content (detailed in Table 3) remained the same for the entire period of the study, while the classes were organized for a period of $30 \mathrm{~min}$ weekly, and it lasted for 10 weeks. The study complied with the required ethical standards, and related approvals were duly obtained from the university before conducting the research.

Table 3. Teaching schedule for both experimental and control group students.

\begin{tabular}{cc}
\hline Week & Topic \\
\hline Week 1 & Explain course outline, give online questionnaire \\
\hline Week 2 & Experiment 1: Ohm's Law \\
\hline Week 3 & Quiz no.1 \\
\hline Week 4 & Experiment 2: Resistances in Series and Parallel \\
\hline Week 5 & Quiz no.2 \\
\hline Week 6 & Experiment 3: Charging and Discharging of RC Circuit \\
\hline Week 7 & Quiz no.3 \\
\hline Week 8 & Experiment 4: Coulomb's Law \\
\hline Week 9 & Quiz no.4 \\
\hline Week 10 & Makeup Exams \\
\hline
\end{tabular}

\subsubsection{Control Group}

A number of the students were in a separate group called the control group. Students in this group were taught using the traditional flipped classroom method.

Pre-class component: Two days before the class for the control group, the researcher prepares a video with a minimum length of $15 \mathrm{mins}$ and a maximum length of $20 \mathrm{~min}$. Also, a related set of quiz questions were provided and uploaded to the available Moodle page. Subsequently, the students did the following:

i. Watch the uploaded video

ii. Solved the quiz questions

iii. Prepared questions regarded the contents they could not understand

In-class component: In continuation of the activities carried out out-of-class, discussion was made during the class about contents that were unclear or not understood by the 
students in the video with the guidance of the instructor. Also, the instructor paid rapt attention to the discussions in order to identify and prevent false learning. It is essential to emphasize that gamification was not used in the control group.

\subsubsection{Experimental Group}

For the experimental group, the students were given a clear description of what to expect throughout the experiment process [43,44]. A description of the gamified flipped learning thus was given to them. Conversely, in order to maintain a clear focus, and deter the participants from wrongfully aiming at high scores only, the grading criteria were not included in the disclosed contents. A summary of the needed information was made into a guideline and made available on Moodle. Below in Figure 2 is the structure of the group.

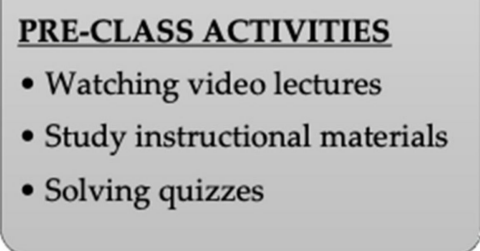

\section{PRE-CLASS ACTIVITIES}

- Solving quizzes

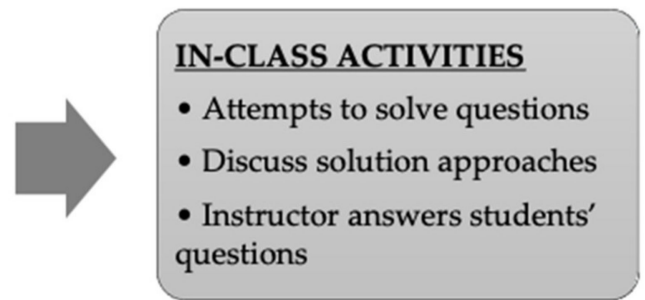

Figure 2. Description of the experimental group activities.

\subsubsection{Gamified Environment}

In order to ensure the effectiveness of the gamification, several elements were employed in the design of the environment. The following elements were used for the gamification environment: badges, experience points, leaderboard, levels, feedback, and timers. Their applications are further described subsequently.

A. Timers: These gamification environment elements are essential in learning applications where time is crucial in the success or failure of a learner. They provide the needed reality of time-constrained real-world activities in the gamified environment. In our study, they were used in order to determine and control the duration of the online quizzes. The timer started with a countdown at the beginning of a scheduled quiz and ended at the end of the quiz period or terminates for a student when they completed the quiz prior to the pre-defined end time (a period of $20 \mathrm{~min}$ ). Prior to the start of the quiz, the students were informed of the quiz details including start and end time, and related instructions. During the period of this study, a total of 4 quizzes were conducted on a fortnight basis, ensuring that the timer was used 4 times.

B. Levels: levels also are crucial elements of the gamification environment [45]. They provide the necessary feedback to students on their performance within the learning platform. With the gamified environment, students could receive feedback on their performance easily by the application of levels [46]. Experience points which were later used in the determination of participants' levels were awarded to students as they progressed in their 'class' activities. Figure 3 shows the level hierarchy and required experience points. All students were enrolled into the entry level 1 which required zero points, and the subsequently work their way up the ladder to level 10, being the highest attainable level in the system with a minimum experience points requirement of 3846 . 


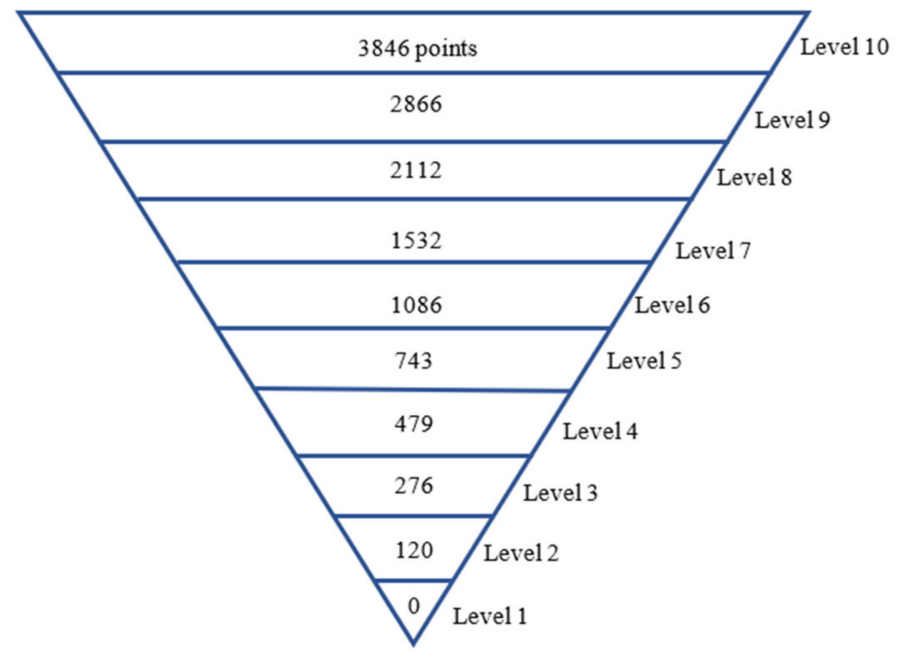

Figure 3. Level hierarchy and required experience points.

C. Experience Points: experience points were computed based on participants' activities, and in turn, were used for the determination of user levels. Starting from zero points at enrollment, students through a selection between their quiz performance and questionnaire responses earn experience points. For the purpose of this study, it was decided that 200 experience points were awarded to each student after a successful submission of their quiz solutions or after a successful submission of a questionnaire among other points awarding criteria. Several actions and events such as repeated actions, administrators' actions were ignored in order to enforce a fair points-awarding system. Figure 4 shows the experience points and its relationship with level.

D. Leaderboard: other than the level element which communicates progress to the participants, the leaderboard introduces a competitive perspective to the progress of the participants. With the leaderboard, participants are encouraged not just to appreciate their performance, but also to compare their performance and recognition with those of other students. This inspires a healthy competition amongst the students to increase their ranks on the leaderboard or maintain a leading position by seeking more achievement and badges [47].

E. Badges: Badges are essential indicators of participant's achievement and success in that they provide a much-needed reward of effort to the gamification participants [42]. They promote social validation as they provide a platform through which users show their conformity to an expected behavior [48]. A single badge (Lab Genius) was used in this study. It is attained when a student obtains a maximum score in all quizzes, it is seen in Figure 5.

F. Feedback: Feedback, a crucial element of gamification serves to both notify participants of mistakes and encourage them to proceed to subsequent activities [49]. Feedback is usually employed to tailor users' activities towards a goal [50]. Due to its enormous significance, feedback has been added to our gamification environment to provide distance-to-goal transparency to students. 


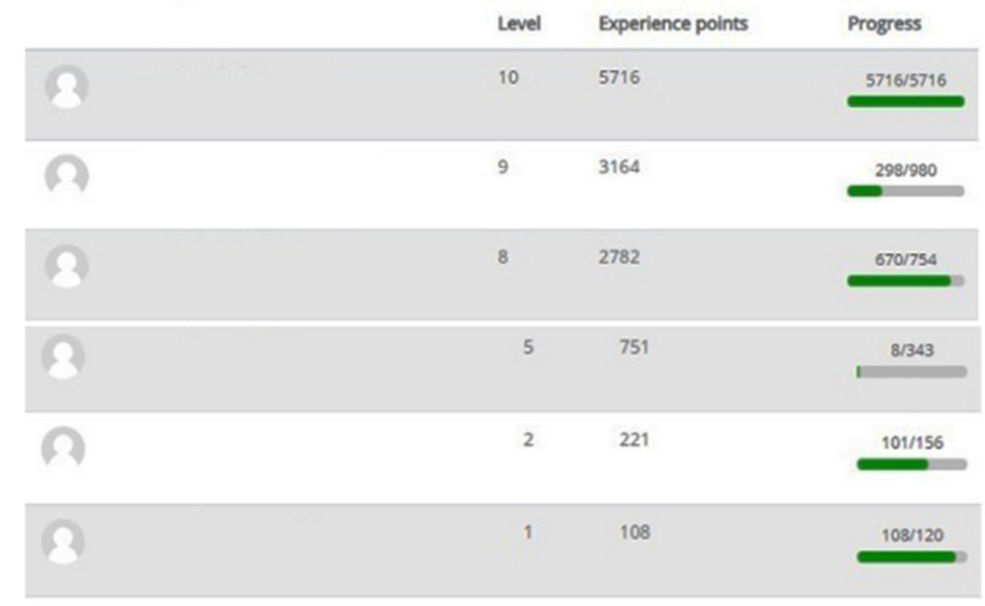

Figure 4. Snapshot of Experience point, showing level ranking.

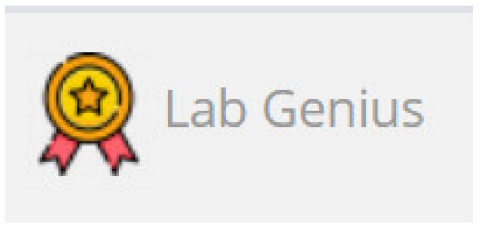

Figure 5. Lab genius badge (obtained after scoring full marks in all quizzes).

\subsection{Data Collection Procedure}

Data for the study was collected through several means. Information was obtained from the participants about their perception of the gamification platform through an interview. Questionnaires were also filled by the participants to enable the researchers to determine the effect of the gamification process on the innovative skills and physics self-efficacy of the respondents. Students had timed quizzes to complete also.

Quiz: Four quizzes were conducted during the study on a fortnight basis. Students studied in a week to learn the required concepts of the course and attempted a quiz in the subsequent week. The entire period allotted for the quiz is announced and monitored by a timer after which students are permitted to make a late-submission. The quizzes were aimed at evaluating if students were able to understand the concepts taught in the video. Students were awarded marks based on the following criteria: students who got all the questions correctly were awarded full marks, those who got not were awarded zero, while missed questions were penalized generally by reducing earned points.

\section{Results}

\subsection{Innovation Skills}

Upon analyzing the questionnaire data on Innovation skills, Table 4 contains the outcomes. 
Table 4. Post-test scores of innovation skill questionnaire.

\begin{tabular}{|c|c|c|c|c|c|c|c|}
\hline Group & & $\mathbf{N}$ & Mean & $\begin{array}{c}\text { Std. } \\
\text { Deviation }\end{array}$ & $\begin{array}{l}\text { Std. } \\
\text { Error Mean }\end{array}$ & $t$ & $p$ \\
\hline \multirow{2}{*}{ I like to think about a new project approach } & Experiment & 35 & 3.6857 & 0.67612 & 0.11429 & 0.77008 & 0.44392 \\
\hline & Control & 35 & 2.9429 & 0.93755 & 0.15847 & & \\
\hline \multirow{2}{*}{$\begin{array}{l}\text { I like to find new challenging to develop new products in my } \\
\text { own discipline }\end{array}$} & Experiment & 35 & 3.5429 & 0.70054 & 0.11841 & 1.881061 & 0.064246 \\
\hline & Control & 35 & 2.9714 & 0.98476 & 0.16645 & & \\
\hline \multirow{2}{*}{ I like to think about how work can be improved } & Experiment & 35 & 3.6571 & 0.68354 & 0.11554 & 0.392134 & 0.696186 \\
\hline & Control & 35 & 2.8857 & 0.86675 & 0.14651 & & \\
\hline \multirow[t]{2}{*}{ I see complex problems as challenging } & Experiment & 35 & 3.6000 & 0.69452 & 0.11739 & 0.255704 & 0.798951 \\
\hline & Control & 35 & 2.6857 & 0.99325 & 0.16789 & & \\
\hline \multirow{2}{*}{ I like to find a new solution to an existing problem } & Experiment & 35 & 3.5143 & 0.61220 & 0.10348 & 0.812523 & 0.419327 \\
\hline & Control & 35 & 2.6286 & 0.87735 & 0.14830 & & \\
\hline \multirow{2}{*}{ I am good at combining different disciplines } & Experiment & 35 & 3.3429 & 0.53922 & 0.09114 & 0.139626 & 0.889438 \\
\hline & Control & 35 & 3.0000 & 0.93934 & 0.15878 & & \\
\hline \multirow{2}{*}{ I can link new ideas to existing ideas (of others). } & Experiment & 35 & 3.4571 & 0.70054 & 0.11841 & 0.669208 & 0.505628 \\
\hline & Control & 35 & 2.8000 & 0.83314 & 0.14083 & & \\
\hline \multirow{2}{*}{ I see my assignment/project as challenging } & Experiment & 35 & 3.4000 & 0.65079 & 0.11000 & 0.888579 & 0.377362 \\
\hline & Control & 35 & 2.9143 & 0.78108 & 0.13203 & & \\
\hline \multirow{2}{*}{ I find my assignment/project field interesting } & Experiment & 35 & 3.4857 & 0.56211 & 0.09501 & 0.230579 & 0.818334 \\
\hline & Control & 35 & 2.8286 & 0.95442 & 0.16133 & & \\
\hline \multirow[t]{2}{*}{ I am is good at my work } & Experiment & 35 & 3.6000 & 0.55307 & 0.09349 & 1.784614 & 0.078785 \\
\hline & Control & 35 & 3.1143 & 0.83213 & 0.14066 & & \\
\hline \multirow{2}{*}{ I can do my core tasks in a routine manner } & Experiment & 35 & 3.5143 & 0.50709 & 0.08571 & 2.001468 & 0.049334 \\
\hline & Control & 35 & 3.2571 & 1.06668 & 0.18030 & & \\
\hline
\end{tabular}

Significant at the 0.05 level.

According to Tables 5 and 6 , it can be said that gamification as a learning approach has a significant effect on students' innovation skills.

Table 5. Scores of innovation skill questionnaire (experimental group).

\begin{tabular}{|c|c|c|c|c|c|c|c|}
\hline Group & & $\mathbf{N}$ & Mean & $\begin{array}{c}\text { Std. } \\
\text { Deviation }\end{array}$ & $\begin{array}{l}\text { Std. } \\
\text { Error Mean }\end{array}$ & $t$ & $p$ \\
\hline \multirow{2}{*}{ I like to think about a new project approach } & Pre-test & 35 & 2.4286 & 0.91670 & 0.15495 & \multirow{2}{*}{6.529} & \multirow[t]{2}{*}{0.023214} \\
\hline & Post-test & 35 & 3.6857 & 0.67612 & 0.11429 & & \\
\hline \multirow{2}{*}{$\begin{array}{l}\text { I like to find new challenging to develop new products in my } \\
\text { own discipline }\end{array}$} & Pre-test & 35 & 2.2000 & 0.93305 & 0.15771 & \multirow[t]{2}{*}{6.809} & \multirow[t]{2}{*}{0.042510} \\
\hline & Post-test & 35 & 3.5429 & 0.70054 & 0.11841 & & \\
\hline \multirow{2}{*}{ I like to think about how work can be improved } & Pre-test & 35 & 2.5429 & 0.91853 & 0.15526 & \multirow{2}{*}{5.758} & \multirow[t]{2}{*}{0.016031} \\
\hline & Post-test & 35 & 3.6571 & 0.68354 & 0.11554 & & \\
\hline \multirow[t]{2}{*}{ I see complex problems as challenging } & Pre-test & 35 & 2.5429 & 0.91853 & 0.15526 & \multirow[t]{2}{*}{5.431} & \multirow[t]{2}{*}{0.019105} \\
\hline & Post-test & 35 & 3.6000 & 0.69452 & 0.11739 & & \\
\hline \multirow{2}{*}{ I like to find a new solution to an existing problem } & Pre-test & 35 & 2.5714 & 0.81478 & 0.13772 & \multirow[t]{2}{*}{5.473} & \multirow[t]{2}{*}{0.007361} \\
\hline & Post-test & 35 & 3.5143 & 0.61220 & 0.10348 & & \\
\hline \multirow{2}{*}{ I am good at combining different disciplines } & Pre-test & 35 & 2.7429 & 0.65722 & 0.11109 & \multirow[t]{2}{*}{4.176} & \multirow[t]{2}{*}{0.000013} \\
\hline & Post-test & 35 & 3.3429 & 0.53922 & 0.09114 & & \\
\hline \multirow{2}{*}{ I can link new ideas to existing ideas (of others). } & Pre-test & 35 & 2.5429 & 0.98048 & 0.16573 & \multirow[t]{2}{*}{4.489} & \multirow[t]{2}{*}{0.013147} \\
\hline & Post-test & 35 & 3.4571 & 0.70054 & 0.11841 & & \\
\hline \multirow{2}{*}{ I see my assignment/project as challenging } & Pre-test & 35 & 2.4857 & 0.91944 & 0.15541 & \multirow[t]{2}{*}{4.802} & \multirow[t]{2}{*}{0.033127} \\
\hline & Post-test & 35 & 3.4000 & 0.65079 & 0.11000 & & \\
\hline \multirow{2}{*}{ I find my assignment/project field interesting } & Pre-test & 35 & 2.6000 & 1.14275 & 0.19316 & \multirow[t]{2}{*}{4.115} & \multirow[t]{2}{*}{0.021576} \\
\hline & Post-test & 35 & 3.4857 & 0.56211 & 0.09501 & & \\
\hline \multirow[t]{2}{*}{ I am is good at my work } & Pre-test & 35 & 2.5143 & 1.03955 & 0.17572 & \multirow[t]{2}{*}{5.455} & \multirow[t]{2}{*}{0.042134} \\
\hline & Post-test & 35 & 3.6000 & 0.55307 & 0.09349 & & \\
\hline \multirow{2}{*}{ I can do my core tasks in a routine manner } & Pre-test & 35 & 2.4286 & 1.00837 & 0.17045 & \multirow[t]{2}{*}{5.691} & \multirow[t]{2}{*}{0.001821} \\
\hline & Post-test & 35 & 3.5143 & 0.50709 & 0.08571 & & \\
\hline
\end{tabular}

Significant at the 0.05 level. 
Table 6. Scores of innovation skill questionnaire (control group).

\begin{tabular}{|c|c|c|c|c|c|c|c|}
\hline Group & & $\mathbf{N}$ & Mean & $\begin{array}{c}\text { Std. } \\
\text { Deviation }\end{array}$ & $\begin{array}{c}\text { Std. } \\
\text { Error Mean }\end{array}$ & $t$ & $p$ \\
\hline \multirow{2}{*}{ I like to think about a new project approach } & Pre-test & 35 & 2.6000 & 0.94558 & 0.15983 & \multirow{2}{*}{1.523} & \multirow[t]{2}{*}{0.132326214} \\
\hline & Post-test & 35 & 2.9429 & 0.93755 & 0.15847 & & \\
\hline \multirow{2}{*}{$\begin{array}{l}\text { I like to find new challenging to develop new products in my } \\
\text { own discipline }\end{array}$} & Pre-test & 35 & 2.6286 & 0.97274 & 0.16442 & \multirow[t]{2}{*}{1.465} & \multirow[t]{2}{*}{0.147423234} \\
\hline & Post-test & 35 & 2.9714 & 0.98476 & 0.16645 & & \\
\hline \multirow{2}{*}{ I like to think about how work can be improved } & Pre-test & 35 & 2.6286 & 0.91026 & 0.15386 & \multirow[t]{2}{*}{1.21} & \multirow[t]{2}{*}{0.23034345} \\
\hline & Post-test & 35 & 2.8857 & 0.86675 & 0.14651 & & \\
\hline \multirow[t]{2}{*}{ I see complex problems as challenging } & Pre-test & 35 & 2.4857 & 0.95090 & 0.16073 & \multirow[t]{2}{*}{0.86} & \multirow[t]{2}{*}{0.392542379} \\
\hline & Post-test & 35 & 2.6857 & 0.99325 & 0.16789 & & \\
\hline \multirow{2}{*}{ I like to find a new solution to an existing problem } & Pre-test & 35 & 2.4000 & 0.94558 & 0.15983 & \multirow[t]{2}{*}{1.048} & \multirow[t]{2}{*}{0.298199693} \\
\hline & Post-test & 35 & 2.6286 & 0.87735 & 0.14830 & & \\
\hline \multirow{2}{*}{ I am good at combining different disciplines } & Pre-test & 35 & 2.7143 & 1.01667 & 0.17185 & \multirow[t]{2}{*}{1.221} & \multirow[t]{2}{*}{0.226243151} \\
\hline & Post-test & 35 & 3.0000 & 0.93934 & 0.15878 & & \\
\hline \multirow{2}{*}{ I can link new ideas to existing ideas (of others). } & Pre-test & 35 & 2.6857 & 0.79600 & 0.13455 & \multirow[t]{2}{*}{0.587} & \multirow[t]{2}{*}{0.559298529} \\
\hline & Post-test & 35 & 2.8000 & 0.83314 & 0.14083 & & \\
\hline \multirow{2}{*}{ I see my assignment/project as challenging } & Pre-test & 35 & 2.6857 & 0.96319 & 0.16281 & \multirow[t]{2}{*}{1.09} & \multirow[t]{2}{*}{0.279366019} \\
\hline & Post-test & 35 & 2.9143 & 0.78108 & 0.13203 & & \\
\hline \multirow{2}{*}{ I find my assignment/project field interesting } & Pre-test & 35 & 2.5429 & 0.91853 & 0.15526 & \multirow[t]{2}{*}{1.276} & \multirow[t]{2}{*}{0.206272517} \\
\hline & Post-test & 35 & 2.8286 & 0.95442 & 0.16133 & & \\
\hline \multirow[t]{2}{*}{ I am is good at my work } & Pre-test & 35 & 2.9429 & 0.96841 & 0.16369 & \multirow[t]{2}{*}{0.794} & \multirow[t]{2}{*}{0.429778596} \\
\hline & Post-test & 35 & 3.1143 & 0.83213 & 0.14066 & & \\
\hline \multirow{2}{*}{ I can do my core tasks in a routine manner } & Pre-test & 35 & 2.9714 & 1.24819 & 0.21098 & \multirow[t]{2}{*}{1.029} & \multirow[t]{2}{*}{0.306897293} \\
\hline & Post-test & 35 & 3.2571 & 1.06668 & 0.18030 & & \\
\hline
\end{tabular}

Significant at the 0.05 level.

\subsection{Physics Self-Efficacy}

Contrary to the observations in Table 3 for innovation skill, Table 7 shows the results of the physics self-efficacy questionnaire, indicating that gamification process did not improve the physics self-efficacy of the students.

Table 7. Post-test scores of physics self-efficacy questionnaire.

\begin{tabular}{|c|c|c|c|c|c|c|c|}
\hline Group & & $\mathbf{N}$ & Mean & $\begin{array}{c}\text { Std. } \\
\text { Deviation }\end{array}$ & $\begin{array}{l}\text { Std. Error } \\
\text { Mean }\end{array}$ & $t$ & $p$ \\
\hline \multirow{2}{*}{$\begin{array}{l}\text { I can understand the important concepts in the physics } \\
\text { lab book }\end{array}$} & Experiment & 35 & 2.9429 & 0.90563 & 0.15308 & 1.413476 & 0.162077 \\
\hline & Control & 35 & 3.3143 & 1.07844 & 0.18229 & & \\
\hline \multirow{2}{*}{$\begin{array}{l}\text { I can design examples about the content of the physics } \\
\text { lab book }\end{array}$} & Experiment & 35 & 2.8286 & 0.70651 & 0.11942 & 0.524651 & 0.601532 \\
\hline & Control & 35 & 3.5143 & 1.14716 & 0.19390 & & \\
\hline \multirow{2}{*}{$\begin{array}{l}\text { I can use my physics knowledge to understand the problem } \\
\text { discussions in the physics lab book }\end{array}$} & Experiment & 35 & 2.8000 & 0.58410 & 0.09873 & 0 & 1 \\
\hline & Control & 35 & 3.4286 & 1.03713 & 0.17531 & & \\
\hline \multirow{2}{*}{$\begin{array}{l}\text { I can write a simple example about any physics subject I } \\
\text { have learned. }\end{array}$} & Experiment & 35 & 2.6857 & 1.02244 & 0.17282 & 0.788443 & 0.433178 \\
\hline & Control & 35 & 3.6000 & 1.00587 & 0.17002 & & \\
\hline \multirow[t]{2}{*}{ I can understand physics lab terms } & Experiment & 35 & 2.9429 & 0.93755 & 0.15847 & 0.674551 & 0.502248 \\
\hline & Control & 35 & 3.6000 & 1.11672 & 0.18876 & & \\
\hline \multirow{2}{*}{$\begin{array}{l}\text { I can make an effective use of my knowledge while solving } \\
\text { physics lab problems. }\end{array}$} & Experiment & 35 & 2.9429 & 0.76477 & 0.12927 & 0.812121 & 0.419556 \\
\hline & Control & 35 & 3.6571 & 1.10992 & 0.18761 & & \\
\hline \multirow{2}{*}{$\begin{array}{l}\text { I can make connections between recently learned subjects and } \\
\text { my physics lab knowledge. }\end{array}$} & Experiment & 35 & 3.0857 & 0.95090 & 0.16073 & 0.636512 & 0.52658 \\
\hline & Control & 35 & 3.5429 & 1.06668 & 0.18030 & & \\
\hline \multirow{2}{*}{ I can discover little things by using physics theorems. } & Experiment & 35 & 2.9143 & 0.85307 & 0.14420 & 0.354133 & 0.724335 \\
\hline & Control & 35 & 3.6571 & 0.96841 & 0.16369 & & \\
\hline \multirow{2}{*}{ I can make connections between physics lab terms. } & Experiment & 35 & 2.9143 & 0.85307 & 0.14420 & 0.678089 & 0.500016 \\
\hline & Control & 35 & 3.5429 & 0.98048 & 0.16573 & & \\
\hline \multirow{2}{*}{$\begin{array}{l}\text { I can interpret a physics lab subject I have seen for the first } \\
\text { time with my previous knowledge. }\end{array}$} & Experiment & 35 & 2.8571 & 0.84515 & 0.14286 & 0.497265 & 0.620606 \\
\hline & Control & 35 & 3.5429 & 0.81684 & 0.13807 & & \\
\hline \multirow{2}{*}{$\begin{array}{l}\text { I can identify the important physics lab points of a physics } \\
\text { lab subject I read about. }\end{array}$} & Experiment & 35 & 2.8857 & 0.79600 & 0.13455 & 0.221579 & 0.825305 \\
\hline & Control & 35 & 3.6000 & 1.14275 & 0.19316 & & \\
\hline
\end{tabular}


Table 7. Cont.

\begin{tabular}{|c|c|c|c|c|c|c|c|}
\hline Group & & $\mathbf{N}$ & Mean & $\begin{array}{c}\text { Std. } \\
\text { Deviation }\end{array}$ & $\begin{array}{l}\text { Std. Error } \\
\text { Mean }\end{array}$ & $t$ & $p$ \\
\hline \multirow{2}{*}{$\begin{array}{l}\text { I know how to behave when I encounter a new challenge in } \\
\text { physics lab. }\end{array}$} & Experiment & 35 & 2.7714 & 0.80753 & 0.13650 & 2.351346 & 0.021611 \\
\hline & Control & 35 & 3.7143 & 1.10004 & 0.18594 & & \\
\hline \multirow{2}{*}{ I believe that I have the ability to learn physics lab. } & Experiment & 35 & 2.9143 & 0.74247 & 0.12550 & 0.480724 & 0.632255 \\
\hline & Control & 35 & 3.8571 & 1.14128 & 0.19291 & & \\
\hline \multirow{2}{*}{$\begin{array}{l}\text { I know how I can make an effective use of my previous } \\
\text { knowledge when I encounter a new challenge in physics lab. }\end{array}$} & Experiment & 35 & 2.9429 & 0.76477 & 0.12927 & 1.579835 & 0.118785 \\
\hline & Control & 35 & 3.8571 & 1.16677 & 0.19722 & & \\
\hline \multirow{2}{*}{$\begin{array}{l}\text { I can use my physics lab knowledge to learn similar concepts } \\
\text { in other lessons. }\end{array}$} & Experiment & 35 & 2.8857 & 0.90005 & 0.15214 & 1.069584 & 0.288588 \\
\hline & Control & 35 & 3.6286 & 1.08697 & 0.18373 & & \\
\hline \multirow[t]{2}{*}{ I can find clues in physics lab problems. } & Experiment & 35 & 2.9429 & 0.99832 & 0.16875 & 0.595367 & 0.553719 \\
\hline & Control & 35 & 3.5714 & 0.94824 & 0.16028 & & \\
\hline \multirow{2}{*}{$\begin{array}{l}\text { I can solve physics lab problems by using } \\
\text { self-specific solutions. }\end{array}$} & Experiment & 35 & 2.8286 & 0.92309 & 0.15603 & 0.118678 & 0.90588 \\
\hline & Control & 35 & 3.4000 & 0.94558 & 0.15983 & & \\
\hline \multirow{2}{*}{ I can concentrate in physics lab sessions. } & Experiment & 35 & 2.7714 & 0.80753 & 0.13650 & 1.037199 & 0.303318 \\
\hline & Control & 35 & 3.8000 & 1.05161 & 0.17775 & & \\
\hline \multirow{2}{*}{$\begin{array}{l}\text { I strongly believe that I can solve a difficult physics } \\
\text { lab problem. }\end{array}$} & Experiment & 35 & 3.0857 & 1.01087 & 0.17087 & 0.210819 & 0.833659 \\
\hline & Control & 35 & 3.6571 & 1.16171 & 0.19637 & & \\
\hline \multirow{2}{*}{$\begin{array}{l}\text { I can guarantee the accuracy of a result I find for a physics } \\
\text { lab problem. }\end{array}$} & Experiment & 35 & 2.8286 & 0.89066 & 0.15055 & 0.212704 & 0.832194 \\
\hline & Control & 35 & 3.5714 & 1.14496 & 0.19353 & & \\
\hline \multirow{2}{*}{ I can get compliments for my physics lab homework. } & Experiment & 35 & 3.0571 & 0.96841 & 0.16369 & 0 & 1 \\
\hline & Control & 35 & 3.6857 & 1.15737 & 0.19563 & & \\
\hline \multirow{2}{*}{$\begin{array}{l}\text { I always have a feeling that I solve a physics lab } \\
\text { problem correctly. }\end{array}$} & Experiment & 35 & 2.9429 & 0.90563 & 0.15308 & 0.107686 & 0.914562 \\
\hline & Control & 35 & 3.6286 & 1.11370 & 0.18825 & & \\
\hline \multirow{2}{*}{ I can get good marks in physics lab exams. } & Experiment & 35 & 3.0286 & 1.09774 & 0.18555 & 0 & 1 \\
\hline & Control & 35 & 3.7714 & 1.00252 & 0.16946 & & \\
\hline \multirow{2}{*}{ I can solve physics lab problems by concretizing them. } & Experiment & 35 & 2.8286 & 0.82197 & 0.13894 & 1.746355 & 0.085265 \\
\hline & Control & 35 & 4.0286 & 1.04278 & 0.17626 & & \\
\hline \multirow{2}{*}{ I can make a good solution plan for physics lab problems. } & Experiment & 35 & 2.9143 & 0.81787 & 0.13824 & 2.31473 & 0.023654 \\
\hline & Control & 35 & 4.0000 & 0.87447 & 0.14781 & & \\
\hline \multirow{2}{*}{ I have my own ideas about questions related to physics lab. } & Experiment & 35 & 3.1143 & 0.90005 & 0.15214 & 0.333819 & 0.739544 \\
\hline & Control & 35 & 3.8571 & 1.11521 & 0.18851 & & \\
\hline \multirow{2}{*}{ I can analyze the event in a physics problem. } & Experiment & 35 & 3.2286 & 1.00252 & 0.16946 & 0.118777 & 0.905803 \\
\hline & Control & 35 & 3.7714 & 1.00252 & 0.16946 & & \\
\hline \multirow{2}{*}{ I study alone to solve problems in the learning step. } & Experiment & 35 & 3.2000 & 1.05161 & 0.17775 & 0 & 1 \\
\hline & Control & 35 & 3.8571 & 1.03307 & 0.17462 & & \\
\hline \multirow{2}{*}{$\begin{array}{l}\text { I think with a physics lab mentality when planning daily } \\
\text { life events. }\end{array}$} & Experiment & 35 & 3.2571 & 1.03875 & 0.17558 & 0.543159 & 0.588823 \\
\hline & Control & 35 & 3.7429 & 1.01003 & 0.17073 & & \\
\hline
\end{tabular}

Significant at the 0.05 level.

Quiz Submission and Performance: The data from quiz submission by the participants were also investigated and is available in Table 8. Considering the number of participants that submitted their quizzes before the deadline, we could establish how the teaching approach was appealing to the students, and their subsequent perception of it. Both groups were examined on PHY102 through 4 quizzes.

Table 8. Students' quiz performance.

\begin{tabular}{ccccccc}
\hline Group & N & Mean & $\begin{array}{c}\text { Std. } \\
\text { Deviation }\end{array}$ & $\begin{array}{c}\text { Std. Error } \\
\text { Mean }\end{array}$ & $\boldsymbol{t}$ & $\boldsymbol{p}$ \\
\hline Control & 140 & 5.32600 & 3.578992 & 0.292223 & 5.615 & 0.00 \\
Experimental & 140 & 7.45886 & 3.079501 & 0.244992 & & \\
\hline
\end{tabular}

Significant at the 0.05 level.

In the same vein, we proceeded to investigate the increase in weekly quiz completion rate represented by plots in Figure 6. It can be seen that $67 \%$ of the participants in the experimental group completed their first quiz as against $38 \%$ in the control group. The interest shown by students in the experimental group was maintained through subsequent quizzes such that by Quiz 4, only 16\% of the students in the experimental group were unable to complete their quiz for whatsoever reasons as against $28 \%$ in the control group. 
The participants' overall quiz completion and pass rates were also studied. It can be seen in Figure 7 that more students in the experimental group completed their quizzes and exceeded set pass thresholds. For the $50 \%$ pass threshold, more than $60 \%$ of students in the experimental group were successful in contrast to $30 \%$ recorded in the control group. Also, while $50 \%$ of participants in the experimental group exceeded the $80 \%$ threshold, only $20 \%$ of students in the control group did.

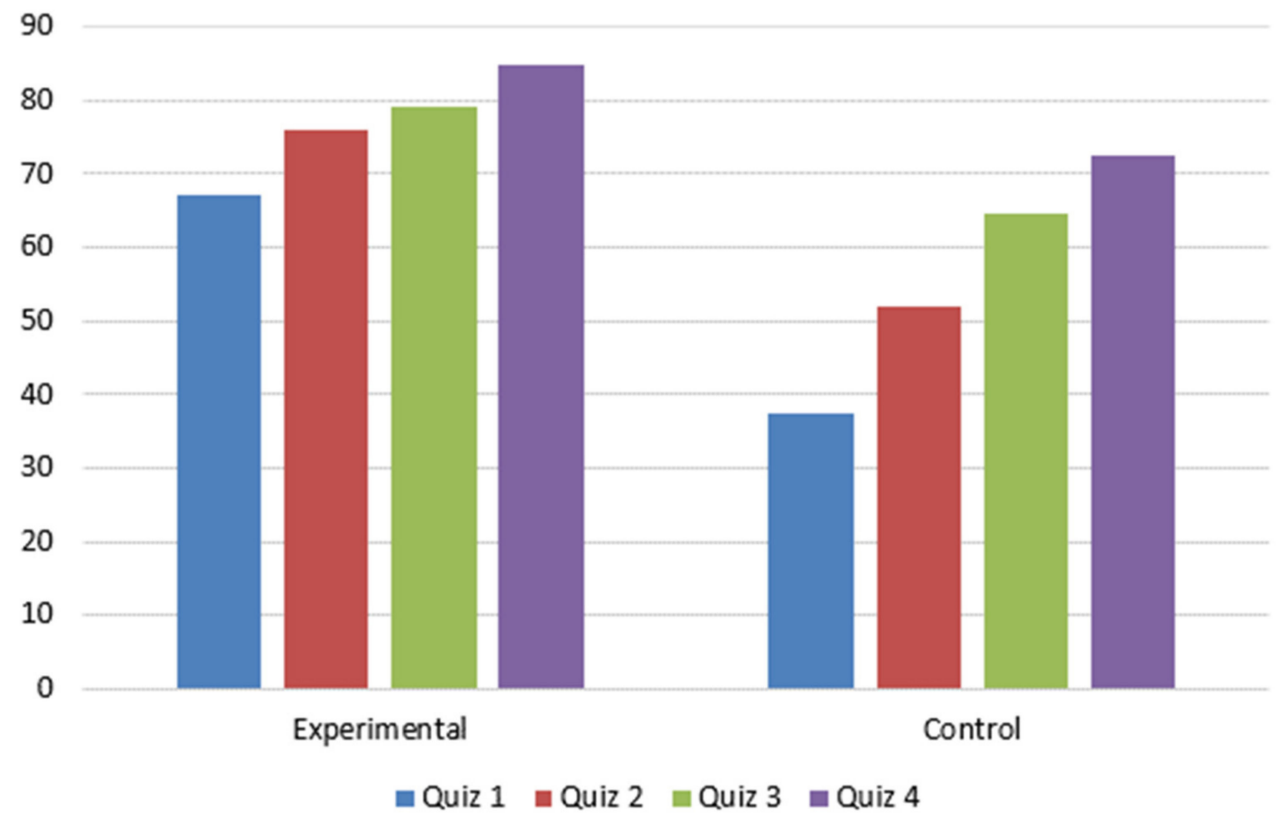

Figure 6. Weekly increase in quiz completion rate (\%).

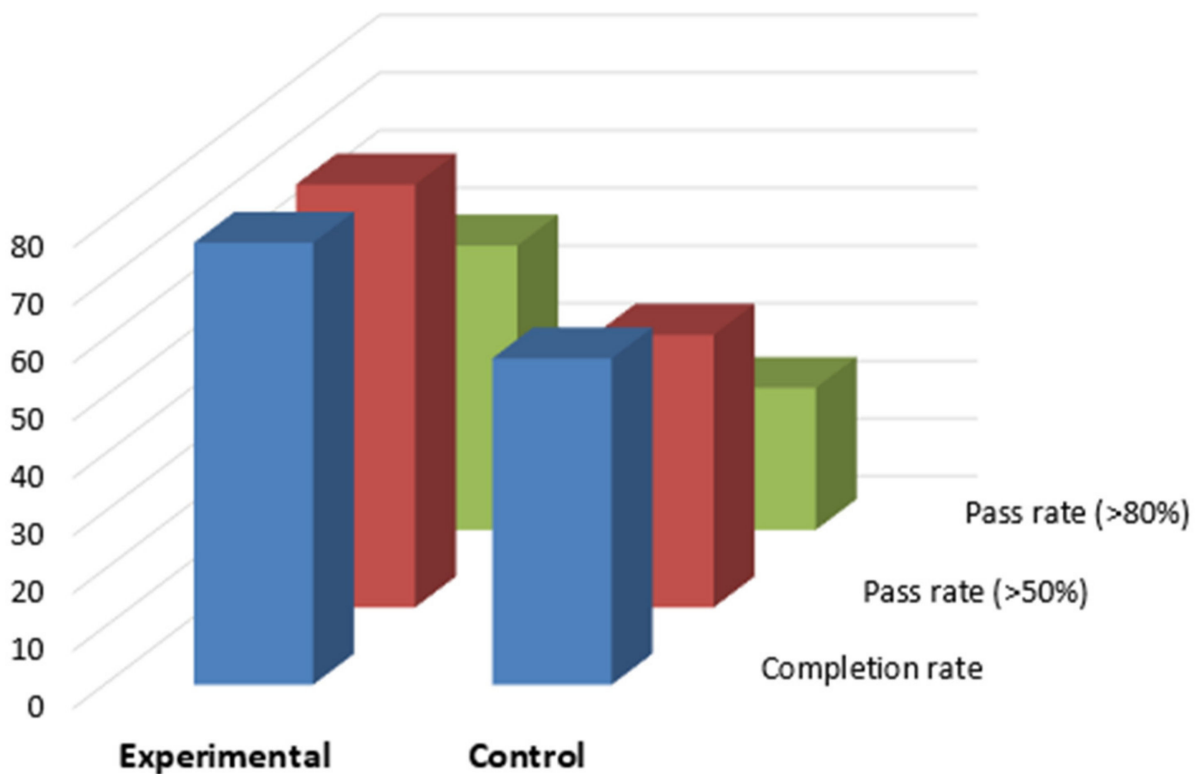

Figure 7. Completion rate and various pass rates observed in both groups.

\subsection{Students' Perception}

Interviews were also conducted with students in the experimental group at the end of the study period to determine their perception of the GFL method. Using thematic analysis, interview responses/transcripts were thoroughly and repeatedly perused to identify patterns in respondents' descriptions of their experiences. Several recurring 
patterns were observed in the study. All the interviewees agreed that the gamification mechanics employed in the research (such as levels, badges, leaderboards, points) increased their motivation for the course, some went further to provide details such as "Seeing my achievements made me happy". In like manner, the students collectively agreed that the provided game mechanics can greatly support their learning.

When asked if the students think that the GFL method is suitable for virtual physics class, most (79\%) of the students perceived that it was, leaving only a handful of students with contrasting opinions which is open to consideration. Among these remaining $21 \%$ with contrasting views, some requested for better "class control", claiming that instructors" physical absence may play a role in students' participation.

When asked about the main advantages of the gamified flipped learning group they had, the respondents unusually provided divergent reasons, but all agreed that there were certain advantages. Their responses varied from "Instant feedback" through "faster result" to "ease of results' reproducibility". The latter two responses show clear benefits of a simulated laboratory experiment which need to be explored further by researchers. Due to the complexity in the process of setting up a physical laboratory experiment session, the time required, and the difficulty of subsequently reproducing exact results due to several uncontrollable phenomenon, the ease of reproducibility and experiment setup in the GFL method appeals to students. On the flip side, when asked about the disadvantages of the gamified flipped learning laboratory sessions, even though more than half (54\%) of the respondents didn't notice a disadvantage, the prevalent challenge among the $46 \%$ remaining responses seems to be "technical issues", as students complained of a few technical challenges they faced in joining and maintaining productive sessions.

While some students perceived the system as perfect or could not figure out a necessary improvement it needs, some others recommended that periodically, it should be mixed with traditional classroom while an interviewee requested for "more games". When asked what courses they perceived as suitable for the GFL method, the opinions were a bit divided as some respondents believed it would be suitable for the science related courses like Physics, Chemistry, and Mathematics while a host of others would love to see it applied to all their courses. Though, not unexpectedly, some students insist that it may be a perfect fit for Physics only since they have only experienced it with Physics. Conclusively, when asked for their future projections about their intention to apply the teaching approach in the future, $82 \%$ of the students would be glad to continue the experience and would love to participate in it in the future due to its identified benefits.

\section{Discussion}

In this study, we have investigated the impacts introduced by gamification and its elements on the innovation and self-efficacy of first year university physics students.

The results of the study have made crucial attempts to provide clarifications on the impacts of the GFL method on recipients in an academic environment (students) within the scope of perception, innovation skills, and self-efficacy of students. The result obtained about innovation in this work is in conformity with the results of [51] in which the improvement to students' innovation was practically marked by their ability to develop a detailed software system. The presence of several elements applied with the experimental group of the study, such as badges and levels were considered to have played significant roles in student's improved innovation skills. Students were able to conduct experiments on their own without an external interference or involvement, and also integrate their creativity in the process of conducting the required experiments.

Participants in the study showed a positive perception of the learning approach, specifically mentioning some key aspects of the process that were outstandingly beneficial. A participant found the "ability to reproduce experiment results without setting up the experiment environment all-over" as an unparalleled benefit of the gamified flipped lab environment because it provides a research environment which is currently unavailable in the conventional laboratory. This unique environment enables studies on varying research 
parameters to be conducted in a short period as time-wasting, repetitive initializations are eliminated from the research process. Several participants indicated that they look forward to gamified flipped learning experiences in other future courses, as $58 \%$ of the respondents recommended that its scope be expanded to other courses. The result of this study was found to corroborate the findings of Lu et al. [52].

In line with the findings in the studies of $[53,54]$, the study identified that no significant improvement was introduced by gamified flipped learning method on student's selfefficacy. Bandura in [55] identified physiological and emotional states as one of four mandatory factors in the development of self-efficacy. Due to the prevalence of COVID19, its accompanying concerns, and other individual physiological challenges such as an unanticipated mandate on students by their respective institutions to adapt to the online academic system, it is believed by the authors that the development of students' self-efficacy suffered. Similarly, physiological and emotional states were identified in [53] as the main deterrent to the improvement of students' self-efficacy.

\section{Limitations of the Study}

Since the study reports the perception, innovation-skills, and self-efficacy of the students in physics lab class, it may be difficult to generalize findings from the study to other fields of study. Also, it is important to identify the perception of the instructor, and this offers a future study.

Also, while the study focuses on the three identified measures, it is essential to recognize that several other measures play irreplaceable roles in the impact of gamified flipped learning methods on students. These other measures need to be investigated in a holistic approach to identify their interplay. Additionally, the duration of the gamified flipped learning (10 weeks) may play a role in the results obtained from the study since the academic calendar in the Near East University is generally longer than 10 weeks. While the study investigated the effects of GFL and FL learning approaches on students, it is needful to conduct other studies that will take the traditional classroom into consideration. Other types of experimental-based classes also need to be considered in future studies. Finally, since the study was conducted within a single university, future studies could consider a diversified approach to the research.

Author Contributions: All authors contributed to several aspects of the study, specifically, conceptualization, G.A.; methodology, G.A. and H.D.A.; formal analysis, the investigation, resources, and data curation, H.D.A. and G.A.; writing—original draft preparation, H.D.A.; writing, review and editing, H.D.A. and G.A.; supervision, G.A. All authors have read and agreed to the published version of the manuscript.

Funding: This research received no external funding.

Institutional Review Board Statement: Not applicable.

Informed Consent Statement: Informed consent was obtained from all subjects involved in the study.

Data Availability Statement: Data sharing not applicable.

Acknowledgments: The authors wish to thank the participating respondents for their time and effort.

Conflicts of Interest: The authors declare no conflict of interest.

\section{References}

1. Hung, C.-Y.; Sun, J.C.-Y.; Liu, J.-Y. Effects of flipped classrooms integrated with MOOCs and game-based learning on the learning motivation and outcomes of students from different backgrounds. Interact. Learn. Environ. 2018, 27, 1028-1046. [CrossRef]

2. Marti-Parreno, J.; Summerfield, L.; Prado-Gasco, V.; Queiro-Ameijeiras, C.; Romero-Reignier, V.; Gimenez-Fita, E. Main Determinants of Teachers' Intention to Use Flipped Classrooms: The Role of Attitude, Perceived Usefulness, and Utilitarian Value. In Proceedings of the EDULearn14: 6th International Conference on Education and New Learning Technologies, Barcelona, Spain, 7-9 July 2014.

3. Lee, Y.H.; Kim, K.-J. Enhancement of student perceptions of learner-centeredness and community of inquiry in flipped classrooms. BMC Med. Educ. 2018, 18, 242. [CrossRef] [PubMed] 
4. Han, E.; Klein, K.C. Pre-Class Learning Methods for Flipped Classrooms. Am. J. Pharm. Educ. 2019, 83, 6922. [CrossRef] [PubMed]

5. Comber, D.P.M.; Brady-Van den Bos, M. Too much, too soon? A critical investigation into factors that make Flipped Classrooms effective. High. Educ. Res. Dev. 2018, 37, 683-697. [CrossRef]

6. Hwang, G.-J.; Lai, C.-L.; Wang, S.-Y. Seamless flipped learning: A mobile technology-enhanced flipped classroom with effective learning strategies. J. Comput. Educ. 2015, 2, 449-473. [CrossRef]

7. Jang, H.Y.; Kim, H.J. A Meta-Analysis of the Cognitive, Affective, and Interpersonal Outcomes of Flipped Classrooms in Higher Education. Educ. Sci. 2020, 10, 115. [CrossRef]

8. Sanchez, D.R.; Langer, M.; Kaur, R. Gamification in the Classroom: Examining the Impact of Gamified Quizzes on Student Learning. Comput. Educ. 2020, 144, 103666. [CrossRef]

9. Zainuddin, Z.; Chu, S.K.W.; Shujahat, M.; Perera, C.J. The impact of gamification on learning and instruction: A systematic review of empirical evidence. Educ. Res. Rev. 2020, 30, 100326. [CrossRef]

10. Rapp, A.; Hopfgartner, F.; Hamari, J.; Linehan, C.; Cena, F. Strengthening gamification studies: Current trends and future opportunities of gamification research. Int. J. Hum.-Comput. Stud. 2019, 127, 1-6. [CrossRef]

11. Landers, R.N.; Armstrong, M.B. Enhancing instructional outcomes with gamification: An empirical test of the TechnologyEnhanced Training Effectiveness Model. Comput. Hum. Behav. 2017, 71, 499-507. [CrossRef]

12. Bai, S.; Hew, K.F.; Huang, B. Does gamification improve student learning outcome? Evidence from a meta-analysis and synthesis of qualitative data in educational contexts. Educ. Res. Rev. 2020, 30, 100322. [CrossRef]

13. Park, S.; Kim, S. Is Sustainable Online Learning Possible with Gamification?-The Effect of Gamified Online Learning on Student Learning. Sustainability 2021, 13, 4267. [CrossRef]

14. Hernández-Fernández, A.; Olmedo-Torre, N.; Peña, M. Is Classroom Gamification Opposed to Performance? Sustainability 2020, 12, 9958. [CrossRef]

15. Barata, G.; Gama, S.; Jorge, J.; Gonçalves, D. Studying student differentiation in gamified education: A long-term study. Comput. Hum. Behav. 2017, 71, 550-585. [CrossRef]

16. Buckley, P.; Doyle, E. Individualising gamification: An investigation of the impact of learning styles and personality traits on the efficacy of gamification using a prediction market. Comput. Educ. 2017, 106, 43-55. [CrossRef]

17. Ding, L. Applying gamifications to asynchronous online discussions: A mixed methods study. Comput. Hum. Behav. 2019, 91, 1-11. [CrossRef]

18. Yin, H.; Chen, Y. How Gamification Affects Students' Engagement and Language Learning Beliefs in Pre-Class Learning of Flipped EFL Courses: A Theoretical Analysis. In Proceedings of the ACM International Conference Proceeding Series, Chengdu, China, 25-27 September 2020; pp. 211-215.

19. Huang, B.; Hew, K.F.; Lo, C.K. Investigating the effects of gamification-enhanced flipped learning on undergraduate students' behavioral and cognitive engagement. Interact. Learn. Environ. 2019, 27, 1106-1126. [CrossRef]

20. Gündüz, A.Y.; Akkoyunlu, B. Effectiveness of Gamification in Flipped Learning. SAGE Open 2020, 10, 1-16. [CrossRef]

21. Zou, D. Gamified flipped EFL classroom for primary education: Student and teacher perceptions. J. Comput. Educ. 2020, 7, 213-228. [CrossRef]

22. Zainuddin, Z.; Shujahat, M.; Chu, S.K.; Haruna, H.; Farida, R. The effects of gamified flipped instruction on learner performance and need satisfaction. Inf. Learn. Sci. 2019, 120, 789-802. [CrossRef]

23. Ivanova, G.; Kozov, V.; Zlatarov, P. Gamification in Software Engineering Education. In Proceedings of the 2019 42nd International Convention on Information and Communication Technology, Electronics and Microelectronics (MIPRO), IEEE, Opatija, Croatia, 20-24 May 2019; pp. 1445-1450.

24. Gulinna, A.; Lee, Y. College Students' Perceptions of Pleasure in Learning-Designing Gameful Gamification in Education. Int. J. E-Learn. 2020, 19, 93-123.

25. Zou, D.; Xie, H.; Wang, F.L.; Kwan, R. Flipped learning with Wikipedia in higher education. Stud. High. Educ. 2020, 45, 1026-1045. [CrossRef]

26. Lucena, F.J.H.; Belmonte, J.L.; Cabrera, A.F.; Torres, J.M.T.; Sánchez, S.P. Academic Effects of the Use of Flipped Learning in Physical Education. Int. J. Environ. Res. Public Health 2019, 17, 276. [CrossRef]

27. Belmonte, J.L.; Cabrera, A.F.; Núñez, J.A.L.; Sánchez, S.P. Formative Transcendence of Flipped Learning in Mathematics Students of Secondary Education. Mathematics 2019, 7, 1226. [CrossRef]

28. Cabrera, A.F.; Parra-González, M.E.; Belmonte, J.L.; Segura-Robles, A. Educational Potentials of Flipped Learning in Intercultural Education as a Transversal Resource in Adolescents. Religions 2020, 11, 53. [CrossRef]

29. Chou, Y. Actionable Gamification: Beyond Points, Badges, and Leaderboards; Octalysis Media: Fremont, CA, USA, 2019.

30. Thorpe, A.S.; Roper, S. The Ethics of Gamification in a Marketing Context. J. Bus. Ethics 2019, 155, 597-609. [CrossRef]

31. Warmelink, H.; Koivisto, J.; Mayer, I.; Vesa, M.; Hamari, J. Gamification of production and logistics operations: Status quo and future directions. J. Bus. Res. 2020, 106, 331-340. [CrossRef]

32. Koivisto, J.; Hamari, J. The rise of motivational information systems: A review of gamification research. Int. J. Inf. Manag. 2019, 45, 191-210. [CrossRef]

33. Aldemir, T.; Celik, B.; Kaplan, G. A qualitative investigation of student perceptions of game elements in a gamified course. Comput. Hum. Behav. 2018, 78, 235-254. [CrossRef] 
34. Jurgelaitis, M.; Čeponienė, L.; Čeponis, J.; Drungilas, V. Implementing gamification in a university-level UML modeling course: A case study. Comput. Appl. Eng. Educ. 2019, 27, 332-343. [CrossRef]

35. Hassan, M.A.; Habiba, U.; Majeed, F.; Shoaib, M. Adaptive gamification in e-learning based on students' learning styles. Interact. Learn. Environ. 2021, 29, 545-565. [CrossRef]

36. Çakıroğlu, Ü.; Başıüyü̈k, B.; Güler, M.; Atabay, M.; Memiş, B.Y. Gamifying an ICT course: Influences on engagement and academic performance. Comput. Hum. Behav. 2017, 69, 98-107. [CrossRef]

37. Kyewski, E.; Krämer, N.C. To gamify or not to gamify? An experimental field study of the influence of badges on motivation, activity, and performance in an online learning course. Comput. Educ. 2018, 118, 25-37. [CrossRef]

38. Putz, L.-M.; Hofbauer, F.; Treiblmaier, H. Can gamification help to improve education? Findings from a longitudinal study. Comput. Hum. Behav. 2020, 110, 106392. [CrossRef]

39. Mullins, J.K.; Sabherwal, R. Gamification: A cognitive-emotional view. J. Bus. Res. 2020, 106, 304-314. [CrossRef]

40. Sánchez, S.P.; Belmonte, J.L.; Cabrera, A.F.; Núñez, J.A.L. Gamification as a Methodological Complement to Flipped Learning-An Incident Factor in Learning Improvement. Multimodal Technol. Interact. 2020, 4, 12. [CrossRef]

41. Tse, W.S.; Choi, L.Y.A.; Tang, W.S. Effects of video-based flipped class instruction on subject reading motivation. Br. J. Educ. Technol. 2017, 50, 385-398. [CrossRef]

42. Lo, C.K.; Hew, K.F. A comparison of flipped learning with gamification, traditional learning, and online independent study: The effects on students' mathematics achievement and cognitive engagement. Interact. Learn. Environ. 2020, 28, 464-481. [CrossRef]

43. Bhat, A. Research Design: Definition, Characteristics, and Types. Available online: https://www.questionpro.com/blog/researchdesign/amp/ (accessed on 25 March 2021).

44. Marczewski, A. Even Ninja Monkeys Like to Play: Gamification, Game Thinking and Motivational Design; CreateSpace Independent Publishing Platform: Scotts Valley, CA, USA, 2015.

45. Prakasa, F.; Emanuel, A. Review of Benefit Using Gamification Element for Countryside Tourism. In Proceedings of the 2019 International Conference of Artificial Intelligence and Information Technology (ICAIIT), Institute of Electrical and Electronics Engineers (IEEE), Ouargla, Algeria, 4-6 March 2019; pp. 196-200.

46. Zichermann, G.; Cunningham, C. Cunningham Gamification by Design: Implementing Game Mechanics in Web and Mobile Apps; O'Reilly Media, Inc.: Newton, MA, USA, 2011; ISBN 1449397670.

47. Seaborn, K.; Fels, D.I. Gamification in theory and action: A survey. Int. J. Hum.-Comput. Stud. 2015, 74, 14-31. [CrossRef]

48. Hamari, J. Do badges increase user activity? A field experiment on the effects of gamification. Comput. Hum. Behav. 2017, 71, 469-478. [CrossRef]

49. Furdu, I.; Tomozei, C.; Kose, U. Pros and Cons Gamification and Gaming in Classroom.: Discovery Service for University of South Carolina. BRAIN Broad Res. Artif. Intell. Neurosci. 2017, 8, 56-62.

50. Mazarakis, A. Using Gamification for Technology Enhanced Learning: The Case of Feedback Mechanisms. Bull. Tech. Comm. Learn. Technol. 2015, 17, 6-9.

51. Ionica, A.C.; Leba, M. Gamification \& Research-Partnership for Innovation. Procedia Econ. Financ. 2015, 23, 671-676. [CrossRef]

52. Lu, A.; Wong, C.S.K.; Cheung, R.Y.H.; Im, T.S.W. Supporting Flipped and Gamified Learning with Augmented Reality in Higher Education. Front. Educ. 2021, 6, 110. [CrossRef]

53. Rachels, J.R.; Rockinson-Szapkiw, A.J. The effects of a mobile gamification app on elementary students' Spanish achievement and self-efficacy. Comput. Assist. Lang. Learn. 2017, 31, 72-89. [CrossRef]

54. Ortiz-Rojas, M.; Chiluiza, K.; Valcke, M. Gamification in Computer Programming: Effects on Learning, Engagement, Self-Efficacy and Intrinsic Motivation. In Proceedings of the 11th European Conference on Games Based Learning (ECGBL), Graz, Austria, 5-6 October 2017; pp. 507-514.

55. Bandura, A. Self-Efficacy in Changing Societies; Cambridge University Press: Cambridge, UK, 1995; ISBN 1139936069. 